\title{
Crown ethers: novel permeability enhancers for ocular drug delivery?
}

Article

Accepted Version

Morrison, P. W.J., Porfiryeva, N. N., Chahal, S., Salakhov, I. A., Lacourt, C., Semina, I. I., Moustafine, R. I. and Khutoryanskiy, V. V. (2017) Crown ethers: novel permeability enhancers for ocular drug delivery? Molecular Pharmaceutics, 14 (10). pp. 3528-3538. ISSN 1543-8392 doi: https://doi.org/10.1021/acs.molpharmaceut.7b00556 Available at https://centaur.reading.ac.uk/72173/

It is advisable to refer to the publisher's version if you intend to cite from the work. See Guidance on citing.

To link to this article DOI: http://dx.doi.org/10.1021/acs.molpharmaceut.7b00556

Publisher: American Chemical Society

All outputs in CentAUR are protected by Intellectual Property Rights law, including copyright law. Copyright and IPR is retained by the creators or other copyright holders. Terms and conditions for use of this material are defined in the End User Agreement.

\section{www.reading.ac.uk/centaur}

\section{CentAUR}


Central Archive at the University of Reading

Reading's research outputs online 


\title{
Crown Ethers: novel permeability enhancers for
}

\section{ocular drug delivery?}

\author{
Peter W. J. Morrison, ${ }^{a, f}$ Natalia N. Porfiryeva, ${ }^{b}$ Sukhmanpreet Chahal, ${ }^{a}$ Ilgiz A. Salakhov, ${ }^{c}$ \\ Charlène Lacourt, ${ }^{d}$ Irina I. Semina, ${ }^{e}$ Rouslan I. Moustafine, ${ }^{b, e}$ Vitaliy V. Khutoryanskiy ${ }^{a, *}$
}

a School of Pharmacy, University of Reading, Whiteknights, PO Box 224, Reading, RG6 6AD, United Kingdom. *Author for correspondence: Tel.: +44(0)118 378 6119. Fax: +44(0)118 378

4644. E-mail: v.khutoryanskiy@reading.ac.uk

${ }^{b}$ Department of Pharmaceutical, Analytical and Toxicological Chemistry, Kazan State Medical University, 49 Butlerov Street, 420012 Kazan, Russian Federation

${ }^{\mathrm{c}}$ Nanopharma Development Ltd, 100 Vosstaniya Street, 420095, Kazan, Russian Federation

${ }^{d}$ E.B.I. (École de Biologie Industrielle), 32, Boulevard du Port, 95094 Cergy Cedex, France

e Central Research Laboratory, Kazan State Medical University, 6/30 Tolstogo Street, 420012

Kazan, Russian Federation

${ }^{\mathrm{f}}$ School of Pharmacy and Pharmaceutical Sciences \& School of Optometry and Vision Sciences, Cardiff University, CF10 3NB (Current address). 
Abstract: Crown ethers are cyclic molecules consisting of a ring containing several ether groups. The most common and important members of this series are 12-crown-4 (12C4), 15crown-5 (15C5), and 18-crown-6 (18C6). These container molecules have the ability to sequester metal ions and their complexes with drugs are able to traverse cell membranes. This study investigated $12 \mathrm{C} 4,15 \mathrm{C} 5$ and $18 \mathrm{C} 6$ for their ability to increase solubility of ocular drugs and enhance their penetration into the cornea. Phase solubility analysis determined crown ethers' ability to enhance the solubility of riboflavin, a drug used for the therapy of keratoconus, and these solutions were investigated for ocular drug permeation enhancing properties. Atomic absorption spectroscopy demonstrated crown ether solutions ability to sequester $\mathrm{Ca}^{2+}$ from corneal epithelia and crown ether mediated adsorption of riboflavin into the stroma was investigated. Induced corneal opacity studies assessed potential toxicity of crown ethers. Crown ethers enhanced riboflavin's aqueous solubility and its penetration into in vitro bovine corneas; the smaller sized crown ethers gave greatest enhancement. They were shown to sequester $\mathrm{Ca}^{2+}$ ions from corneal epithelia, doing so loosens cellular membrane tight junctions thus enhancing riboflavin penetration. Induced corneal opacity was similar to that afforded by benzalkonium chloride and less than is produced using polyaminocarboxylic acids. However, in vivo experiments performed in rats with $12 \mathrm{C} 4$ did not show any statistically significant permeability enhancement compared to enhancer-free formulation.

Keywords: Crown ethers, corneal epithelium, ocular drug delivery, riboflavin, permeability enhancement, toxicity, in vitro-in vivo correlation. 


\section{Introduction}

Eye drops are generally the preferred means to apply medication when treating ocular disorders; they are convenient and easy to use for most patients. However, this has difficulties despite the fact that the eye is easily accessible since effective drug delivery requires several barriers to be overcome. With aqueous formulations, delivering lipophilic or poorly water soluble drugs at an effective concentration is problematic as is blinking, tear washout and nasolacrimal drainage mechanisms. Up to $90 \%$ of the instilled dose is lost almost immediately; more is absorbed systemically to be eliminated by metabolic processes. It is estimated that $<1 \%$ of the instilled dose penetrates into the eye. ${ }^{1,2}$ When medication is introduced onto the eye there remains only a short time during which the drug can penetrate the cornea. ${ }^{3}$

Corneal epithelium is a lipophilic structure with tight junctions at the superficial cell layers. This layer offers a resistant barrier which impedes penetration of drug molecules in aqueous solution. However, the underlying stroma, which comprises $\sim 90 \%$ of the cornea thickness has a hydrophilic gel-like structure and drugs in aqueous solution easily diffuse throughout this layer. ${ }^{3,4}$

Keratoconus is a debilitating condition of the cornea which can be treated using riboflavin to initiate ultraviolet ' $A$ ' induced collagen cross-linking. ${ }^{5}$ This treatment has become routine practice for the treatment of keratoconus and other corneal disorders. ${ }^{6-9}$ However, the procedure relies on the physical removal of the epithelium under local anaesthesia to allow stromal penetration of riboflavin. ${ }^{5}$ Developing a means to deliver riboflavin into the cornea without removal of the epithelium would be a significant improvement over the current procedure.

Compounds that are effective at extracting $\mathrm{Ca}^{2+}$ ions have been reported to enhance ocular drug permeability. ${ }^{10}$ Polyaminocarboxylic acids are a class of compound well known for $\mathrm{Ca}^{2+}$ 
sequestration ${ }^{11-14}$ and we have demonstrated this in a recent study using calcium chelators for improved ocular drug delivery. ${ }^{15}$

Crown ethers are a class of synthetic macrocyclic polyether molecules first synthesized in the 1960 's. ${ }^{16}$ With their electron rich hydrophilic cavity due to the lone pairs associated with their oxygen atoms (where cation binding occurs), these molecules have a hydrophobic molecular ring structure, and are able to form guest-host complexes with metal ions and neutral organic molecules. It is thought that these ligands have better affinity to the metal cation on the basis of what fits in the inner cavity. The 'cavity-size' relationship was initially used as the underlying concept to explain binding strength and selectivity and suggested that the binding strength will be highest when the ionic diameter of a cation and the cavity of the crown ether are equal. ${ }^{17}$ However, this principle has been revised with the most significant factors now considered to be pre-organisation and complementarity, solvation and chelate ring size. ${ }^{18}$ The inherent flexibility of crown ethers allows them to adapt to a range of environments, displaying solubility in aqueous and lipophilic solvents and 'rapid, reversible ion binding characteristics' ${ }^{18}$ According to the Hansch lipophilicity scale, 18C6 has a value of zero, indicating a perfect hydrophilic / lipophilic balance. This is due to the ligand's ability to flex according to the medium it encounters, exposing either hydrophilic oxygen atoms or lipophilic ethylenic groups. ${ }^{18}$ This is desirable for ocular drug delivery since the physiology of the eye means that a formulation has to traverse lipid and aqueous phases, and the relatively short residence time means enhancing permeation will allow for greater drug absorption.

Crown ethers have uses in many fields; chemistry, biology, industrial and pharmacological research. Their complexes are able to cross cellular membranes. ${ }^{19-21}$ Crown ethers are used in other therapeutic areas, such as tumour treatment, ${ }^{22}$ and they have been investigated for 
enhancement of drug delivery via vesicular formulations, ${ }^{23,24}$ but as far as we know they have not been investigated for ocular drug delivery. We hypothesized that if these compounds can form complexes with calcium ions they should be able to make the cornea more permeable to drugs by extracting $\mathrm{Ca}^{2+}$, thereby loosening epithelial tight junctions, and their ionophoric properties could assist transit of polyether/drug complexes across corneal epithelium.

In this study we investigated the effects of 3 cyclic polyethers of increasing ethylene oxide units, $12 \mathrm{C} 4,15 \mathrm{C} 5$ and $18 \mathrm{C} 6$ for their ability to bind and extract $\mathrm{Ca}^{2+}$ and whether they afford any enhancement to the solubility of riboflavin and its corneal penetration. Isothermal titration calorimetry (ITC) was used to analyse their $\mathrm{Ca}^{2+}$ binding properties and atomic absorption spectrometry (AAS) employed to determine their ability to extract $\mathrm{Ca}^{2+}$ from corneal epithelium. High performance liquid chromatography (HPLC) was employed to determine riboflavin solubility enhancement and in vitro experiments using Franz diffusion cells (FDC) to determine drug permeation through whole corneas. Bovine corneal opacity and permeability (BCOP) was used to determine toxicological implications from the use of crown ethers. In vivo experiments were performed in rats, but did not establish any statistically significant ocular permeability enhancement in live animals.

\section{Materials and Methods}

Materials. Crown ethers (12C4, 15C5 and 18C6), 2-( $N$-morpholino)ethanesulfonic acid (MES), riboflavin, glacial acetic acid, sodium hexane-1-sulfonate monohydrate, benzalkonium chloride (BAC), ethylenediaminetetraacetic acid (EDTA) and fluorescein sodium salt were supplied by Sigma-Aldrich (Gillingham, UK). Calcium calibration standard (1000 ppm), 10\% w/v lanthanum chloride, calcium chloride, potassium chloride, sodium chloride, sodium phosphate, potassium 
dihydrogen phosphate, sodium hydroxide $(\mathrm{NaOH})$, hydrochloric acid, optimal cutting temperature compound (OCT), and HPLC grade ethanol were obtained from Fischer Scientific (Hemel Hempstead, UK). Vectashield mounting medium with 4',6-diamidino-2-phenylindole (DAPI) was obtained from Vector Laboratories Ltd (Peterborough, UK). Ultrapure water (18 $\mathrm{m} \Omega \mathrm{cm}^{-1}$ ) was used for all aqueous solutions and all materials were used as supplied without modification.

\section{Preparation of buffer solutions}

Isotonic phosphate buffered saline (PBS) $\mathrm{pH} 7.4 \pm 0.2,10 \mathrm{mM}$ 2-( $N$-morpholino)ethanesulfonic acid buffer (MES) pH $7.4 \pm 0.2$ and $0.005 \mathrm{M}$ sodium hexane-1-sulfonate, $\mathrm{pH} 3.0 \pm 0.2$ (ion-pair buffer) was prepared in-house using established protocol. $0.005 \mathrm{M}$ ion-pair buffer for HPLC analysis was prepared by dissolving $1.8822 \mathrm{~g}$ sodium hexane-1-sulfonate monohydrate to 1800 $\mathrm{mL}$ ultrapure water adjusted to $\mathrm{pH} 3.0 \pm 0.2$ using glacial acetic acid then made up to $2000 \mathrm{~mL}$ with ultrapure water and filtered to $0.2 \mu \mathrm{m}$. For isothermal titration calorimetry, $10 \mathrm{mM}$ MES buffer was prepared by dissolving $390.48 \mathrm{mg} 2$-( $N$-morpholino)ethanesulfonic acid in $180 \mathrm{~mL}$ ultrapure water adjusted to $\mathrm{pH} 7.4 \pm 0.2$ using $1 \mathrm{M} \mathrm{NaOH}$ solution then made up to $200 \mathrm{~mL}$ with ultrapure water and filtered to $0.2 \mu \mathrm{m} .{ }^{25,26}$

\section{HPLC analysis for in vitro experiments}

HPLC analysis was conducted using a Perkin Elmer series 200 system including UV-Vis detector, quaternary pump and autosampler (Perkin Elmer Inc, UK), a $150 \mathrm{~mm} \times 4.1 \mathrm{~mm}, 10 \mu \mathrm{m}$, reversed phase column, part number: 79425 (Hamilton Company, USA) and PeakSimple data acquisition software version 4.09 (SRI Inc, USA). Riboflavin analysis was achieved using the method previously developed by us. Briefly, isocratic analysis over 5 minutes at $25^{\circ} \mathrm{C}, 0.8 \mathrm{~mL}$ per minute pre-mixed mobile phase consisting of $20 \%$ ethanol and $80 \%$ ion-pair buffer, $267 \mathrm{~nm}$ 
wavelength, $10 \mu \mathrm{L}$ injection volume and riboflavin retention time of 3.05 minutes. Analysis was quantified against a calibration curve produced from riboflavin standards in PBS, pH $7.4 \pm 0.2$ with a range of concentrations between 0.01 to $25 \mu \mathrm{g} \mathrm{mL} \mathrm{m}^{-1}\left(\mathrm{r}^{2}=0.9996\right) .{ }^{15}$

\section{Atomic absorption spectroscopy}

Calcium analysis was achieved using a novAA 350 system with WinAAS software, version 4.5.0 (Analytik JENA, Germany). The analytical method as published by Whiteside and Milner was followed; $50 \mathrm{~mm}$ stoichiometric air/acetylene flame, $422.7 \mathrm{~nm}$ wavelength, ultrapure water (18 $\mathrm{m} \Omega \mathrm{cm}^{-1}$ ) as the carrier. ${ }^{27}$ Analysis was quantified against a calibration curve produced from aqueous $\mathrm{Ca}^{2+}$ standards with 5\% lanthanum chloride as a releasing agent. Standards were prepared at concentrations between 0.1 to $10.0 \mathrm{ppm}\left(\mathrm{r}^{2}=0.9921\right)$.

\section{Isothermal titration calorimetry}

$\mathrm{Ca}^{2+} /$ crown ether binding properties were determined using isothermal titration calorimetry (ITC). A Microcal calorimeter, model ITC200 with software version 1.24.2 (MicroCal Inc. USA). Ultrapure water was put in the reference cell and a reference power of $10 \mu \mathrm{Cal} \mathrm{s} \mathrm{s}^{-1}$ was selected. $5 \mathrm{mM}$ solutions of crown ethers $(12 \mathrm{C} 4,15 \mathrm{C} 5$, and 18C6) in $10 \mathrm{mM}$ MES buffer (pH $7.4 \pm 0.2$ ) were titrated by $100 \mathrm{mM} \mathrm{CaCl}_{2}$ in $10 \mathrm{mM}$ MES buffer. Following the first (redundant) injection at $0.4 \mu \mathrm{L}, 15$ further $2 \mu \mathrm{L}$ injections were made with a spacing of 2.5 minutes and temperature of $25^{\circ} \mathrm{C}$. Graphical analysis performed using Origin $7 \mathrm{SR} 4$, v7.0552 software (OriginLab Corporation, USA).

\section{Preparation of animal tissues}

Fresh bovine eyes were sourced from a local abattoir (P C Turners, Farnborough, UK) and used within 24 hours after slaughter. Experiments to determine calcium extraction and corneal 
opacity experiments employed whole eyes and excised corneas were used for in vitro permeability studies using Franz diffusion cells. All experiments were triplicated with a separate eye or cornea used for each repeat.

\section{Whole eye experiments}

We have previously reported an experimental technique that we developed to investigate corneal exposure to drug formulation $\mathrm{ns}^{28}$ the same protocol was employed in this investigation to determine $\mathrm{Ca}^{2+}$ extraction from corneal epithelia. Briefly, individual eyes were placed in beakers, cornea uppermost and packed with loosely rolled up clingfilm to prevent movement, Franz diffusion cell donor compartments were placed over the cornea and held in place by wrapping the whole assembly with clingfilm ensuring a good seal on the eye, the beakers were placed in a water bath at $34{ }^{\circ} \mathrm{C}$. After 10 minutes equilibration the corneas were exposed to aqueous crown ether solutions at either $1 \mathrm{mg} \mathrm{mL}^{-1}$ or $30 \mathrm{mg} \mathrm{mL}^{-1}$ at $\mathrm{pH} 7.4 \pm 0.2$. After three hours exposure the solutions were recovered, centrifuged at $10000 \mathrm{rpm}(10 \mathrm{~g})$ for ten minutes. Aliquots of each supernatant were diluted by a factor of 100 in $0.25 \%$ aqueous $\mathrm{LaCl}_{3}$ solution for analysis by AAS.

\section{Effect of crown ethers on riboflavin solubility}

A series of aqueous crown ether solutions were prepared at 1, 10, 20 and $30 \mathrm{mg} \mathrm{mL}^{-1}$ for each molecular variant, $12 \mathrm{C} 4,15 \mathrm{C} 5$ and $18 \mathrm{C} 6$. To each solution an excess riboflavin was added at 1 $\mathrm{mg} \mathrm{mL}^{-1}$, and an aqueous solution of saturated riboflavin was used as a control. These solutions were kept in glass vials, wrapped in aluminium foil and stirred overnight at room temperature. Riboflavin saturated solutions were filtered using $0.2 \mu \mathrm{m}$ Minisart ${ }^{\circledR}$ syringe filters, then diluted with ultrapure water by a factor of 10 for HPLC analysis. Our previous studies have shown riboflavin to be photodegradable, ${ }^{28}$ and this agrees with data reported by Terekhova et. al. ${ }^{29}$ 
therefore all experiments and samples were shielded from light using aluminium foil prior to analysis. The association constants of complexation for the crown ethers and riboflavin were calculated using Equation 1.

$$
K_{a: b}=\frac{\text { slope }}{\left[S_{0}\right][1-\text { slope }]}
$$

Where $K_{a: b}$ is the association constant, $S_{0}$ is the intrinsic aqueous solubility of riboflavin and slope is the gradient given by the equation of the graph for riboflavin solubility in crown ether solutions. ${ }^{30,31}$

Riboflavin solubility enhancement using crown ethers was calculated using Equation 2.

$$
R F_{\text {Crown }}(\%)=\frac{\Delta R F}{R F_{\text {water }}} \times 100 \%
$$

Where $R F_{\text {Crown }}(\%)$ is crown ether enhanced riboflavin concentration, $\Delta R F$ is the difference between enhanced riboflavin concentration and the intrinsic aqueous concentration of riboflavin and $R F_{\text {water }}$ is the intrinsic aqueous concentration of riboflavin.

\section{Effect of crown ethers on riboflavin permeability}

Solutions of $12 \mathrm{C} 4,15 \mathrm{C} 5$ and $18 \mathrm{C} 6$ crown ethers at concentration of 1 and $30 \mathrm{mg} \mathrm{mL}^{-1}$ in $\mathrm{PBS}$, $\mathrm{pH} 7.4 \pm 0.2$ were prepared; riboflavin was added at $0.08 \mathrm{mg} \mathrm{mL}^{-1}$ to dissolve. A solution of riboflavin in PBS, pH $7.4 \pm 0.2$ was also prepared at the same concentration as a control. Riboflavin permeability was measured using fresh bovine corneas fitted epithelium uppermost in standard Franz diffusion cells (FDC), each cell having an exposed area of cornea of $1.54 \mathrm{~cm}^{2}$. 16.5 mL of PBS was placed in the receiving chamber. Prepared FDCs were placed in a water

bath, stirred at $34^{\circ} \mathrm{C} \pm 1{ }^{\circ} \mathrm{C}$ to mimic the physiological temperature at the corneal surface..$^{32,33} 1$ 
$\mathrm{mL}$ of aqueous crown ether solutions, and control was added to the donor compartments which were then covered to prevent evaporation. $0.4 \mathrm{~mL}$ aliquots were sampled every hour for 4 hours using sink conditions. Analysis by HPLC was carried out immediately after all samples had been collected to avoid drug degradation. Apparent permeability and steady-state flux were calculated using Equation 3.

$$
P_{a p p}=\frac{\Delta Q}{\Delta t 60 A C_{0}}
$$

Where $P_{a p p}$ is the apparent permeability of riboflavin through bovine cornea, $Q$ is total drug permeated at time $t, \Delta Q / \Delta t$ is the steady-state flux into the receiving solution $\left(\mu \mathrm{mol} \mathrm{min}{ }^{-1}\right)$ which equates to the gradient of the linear portion of the graph, 60 is minutes to seconds conversion factor, $A$ is the area of exposed cornea $\left(1.54 \mathrm{~cm}^{2}\right)$ and $C_{o}$ is the initial amount of drug added to the donor chamber. ${ }^{31}$

\section{Cornea extracts}

Crown ether exposed corneas from the riboflavin permeability experiments were trimmed of scleral tissue, blotted dry and placed in vials containing $5 \mathrm{~mL}$ absolute ethanol to extract riboflavin. They were wrapped in foil, placed in a box and stored at room temperature for 3 days. After extraction, $1 \mathrm{~mL}$ of the extraction solvent was centrifuged for 10 minutes at $10000 \mathrm{rpm}$ (10 g) and the supernatant analysed by HPLC. After riboflavin extraction the corneas were placed in an oven at $40^{\circ} \mathrm{C}$ overnight to dry and their weight recorded to allow calculation of absorbed riboflavin per mg dry corneal tissue. 


\section{Toxicological investigation}

Normal cornea's are transparent and impermeable to fluorescein dye due to tight junctions in the corneal epithelium. ${ }^{34}$ Application of a substance which can denature proteins or cause corneal injury, leading to permeation of the fluorescein dye, reflects toxicological effects to the epithelium. Using a method established in the Bovine Cornea Opacity/Permeability Test ${ }^{35}$ (BCOP) described in, ${ }^{34}$ a scale of epithelial damage and fluorescent intensity was compiled. Corneal opacity and permeability was evaluated using the BCOP test in order to explore toxicological characteristics of crown ethers in comparison to known penetration enhancers and irritants, i.e. benzalkonium chloride and sodium hydroxide. Fresh whole bovine eyes were placed in cups which were subsequently placed in $150 \mathrm{~mL}$ beakers, with the corneas facing uppermost. A few drops of PBS were applied to the corneal surface, the beaker was placed in a closed water bath at $34^{\circ} \mathrm{C} \pm 1{ }^{\circ} \mathrm{C}$ and allowed to equilibrate for 10 minutes. A silicon ring was placed on top of the cornea and $0.1 \mathrm{~mL}$ of various solutions was applied, including PBS, $18 \mathrm{C} 61$ and $30 \mathrm{mg} \mathrm{mL}^{-1}, 15 \mathrm{C} 51$ and $30 \mathrm{~mL}^{-1}, 12 \mathrm{C} 430 \mathrm{~mL}^{-1}$, EDTA $1 \mathrm{mg} \mathrm{mL}^{-1}$, BAC $0.02 \%$, BAC $0.1 \%$, BAC $0.5 \%$, BAC $1 \%, \mathrm{BAC} 2 \%$ and $\mathrm{NaOH} 0.5 \mathrm{M}$ and $1 \mathrm{M}$. The test solution was left on for 30 seconds before being washed off with $10 \mathrm{~mL}$ PBS. The beaker was then incubated for a further 10 minutes $34^{\circ} \mathrm{C} \pm 1^{\circ} \mathrm{C}$. The eye was then removed from the beaker and photographed with the silicon ring still in place using a Logitech webcam C920-C, images included in supporting information (Table S1). Then $0.1 \mathrm{~mL}$ of $2 \% \mathrm{w} / \mathrm{v}$ fluorescein dye solution was placed in the ring and left for 1 minute. The ring was removed and the dye was washed off with $10 \mathrm{~mL}$ PBS. The eye was observed under the fluorescence microscope and the fluorescence image was acquired with the exposure set to $130 \mathrm{~ms}$, images included in supporting information (Table S2). Both sets of images were processed using ImageJ 1.50b software V 1.8.0_60. Each photograph 
was converted to 8-bit images, then the mean grey area function was used to measure opacity for the images, data included in supporting information, (Table S3). Fluorescence image data shown in supporting information (Table S4). The aim of this experiment was to assess any toxicity of crown ethers in comparison to known irritants, e.g. $\mathrm{NaOH}$, and $\mathrm{BAC} 0.02 \%$ which is often used as a preservative and also as a penetration enhancer in ocular formulations.

\section{In vivo experiments}

All in vivo experiments reported in this work were approved by the Ethical committee of Kazan State Medical University (approval no 5 from $28^{\text {th }}$ May 2012). These experiments were conducted with $0.08 \mathrm{mg} \mathrm{mL}^{-1}$ riboflavin solutions with and without $30 \mathrm{mg} \mathrm{mL}^{-1} 12 \mathrm{C} 4$. These experiments were performed in 3 months Wistar male rats weighting 200-250 g. Animals were housed in stainless steel cages and were fed with a standard multi-ration pellets for rodents (Effect Ltd, Chapaevsk, Russian Federation) and had unlimited access to water. Each formulation was tested in 3 animals. Each animal received $2 \mathrm{~mL}$ of the drug solution into both eyes, gradually instilled within 40 minutes. Then animals were sacrificed with a guillotine; both eyes were enucleated using scissors, weighed, quickly washed with $1 \mathrm{~mL}$ of $0.9 \%$ saline solution and placed into $1 \mathrm{~mL}$ methanol for the drug extraction. Extraction was continued in a refrigerator at $4^{\circ} \mathrm{C}$ for 24 hours; $0.2 \mathrm{~mL}$ of each extract was then mixed with $0.8 \mathrm{~mL} 0.1 \%$ of aqueous orthophosphoric acid followed by HPLC analysis. Separate experiments were performed to evaluate the retention of sodium fluorescein solutions on corneal surface in rats $(\mathrm{n}=3)$. A single drop of $1 \mathrm{mg} \mathrm{mL} \mathrm{mL}^{-1}$ sodium fluorescein solution $(\sim 0.05 \mathrm{~mL})$ was administered on rat's cornea; UV light at $254 \mathrm{~nm}$ (VL-6.LC, Vilber Lourmat) was briefly shone into their eye to 
ensure the dye detection, which under these conditions showed green fluorescence, and digital images were taken immediately and 5 minutes after drop administration.

\section{Histological studies}

All histological experiments were conducted similarly to the experiments on in vivo administration of riboflavin described in the previous section. Following 40 minutes administration of $1 \mathrm{~mL} 0.08 \mathrm{mg} \mathrm{mL}^{-1}$ riboflavin solution with and without $30 \mathrm{mg} \mathrm{mL}^{-1} 12 \mathrm{C} 4$ $(n=3)$, rats were sacrificed with a guillotine; their eyes were enucleated and mounted in OCT and kept on dry ice. Cross-sectioning of each corneal segment was performed on a cryostat (Thermo Scientific Microm HM 525) and fixed on glass slides followed by application of 50-75 $\mu \mathrm{L}$ of 1.5 $\mu \mathrm{g} \mathrm{mL} L^{-1}$ DAPI to stain the cell nuclei. Cross sections of rat's cornea were examined using fluorescence microscopy (Olympus BX63); each image was taken using DAPI (blue, maximum $\left.\lambda_{\text {emission }}=461 \mathrm{~nm}\right)$.

\section{HPLC analysis for in vivo experiments}

In order to improve the sensitivity of riboflavin detection in the eye extracts from in vivo experiments, a novel HPLC method was developed. HPLC analysis was conducted using a manual injection LC-20 Prominence HPLC system (Shimadzu, Japan) including SPO-20AV UV-vis detector, CTO-20A column oven, LC-20 AD-U solvent manager and Ascentis C18 column, $25 \mathrm{~cm} \times 4.6 \mathrm{~mm}, 10 \mu \mathrm{m}$ (part number: 581351-U), and data acquisition software (LCsolution version 1.25). Riboflavin analysis was achieved with a run time of 6 min at $40{ }^{\circ} \mathrm{C}$. 
The mobile phase consisted of a mixture of $84 \mathrm{vol} \%$ of 0.1 vol \% aqueous orthophosphoric acid and 16 vol \% acetonitrile, with a flow rate of $1.0 \mathrm{~mL} \mathrm{~min}^{-1}, 445 \mathrm{~nm}$ wavelength, $10 \mu \mathrm{L}$ injection volume and riboflavin retention time of $4.9 \mathrm{~min}$. Analysis was quantified against a calibration curve produced from $0.02,0.03,0.05,0.1,0.2$, and $1.0 \mu \mathrm{g} \mathrm{mL} \mathrm{m}^{-1}$ riboflavin standards $\left(\mathrm{r}^{2}=\right.$ 0.9994). The results of these experiments are calculated in $\mu \mathrm{g}$ of riboflavin per $1 \mathrm{~g}$ of fresh eye $\left(\mu \mathrm{g} \mathrm{g}^{-1}\right)$

\section{Statistical analysis}

Minitab ${ }^{\circledR}$ statistical analysis software package, version 16.2.4 was used to analyse data acquired during these experiments using one-way analysis of variance (ANOVA) and paired t-tests. Probability of $P<0.05$ was considered significant and a minimum of triplicate experiments were used to determine this. Results are reported as the mean \pm standard deviation.

\section{Results and Discussion}

\section{Crown ether enhanced aqueous solubility of riboflavin}

It was shown that $12 \mathrm{C} 4$ at $1 \mathrm{mg} \mathrm{mL}^{-1}$ offered a slight reduction in riboflavin solubility at $0.074 \pm$ $0.003 \mathrm{mg} \mathrm{mL}^{-1 * *}$ compared to the intrinsic aqueous solubility of riboflavin of $0.081 \pm 0.004 \mathrm{mg}$ $\mathrm{mL}^{-1},{ }^{28,36,37}$ whilst all other crown concentrations 10,20 and $30 \mathrm{mg} \mathrm{mL}^{-1}$ enhanced the solubility of riboflavin at $0.088 \pm 0.003,0.099 \pm 0.004$ and $0.110 \pm 0.004 \mathrm{mg} \mathrm{mL}^{-1}$, respectively.** $15 \mathrm{C} 5$ crown ethers at 1, 10, 20 and $30 \mathrm{mg} \mathrm{mL}^{-1}$ all enhanced riboflavin solubility to $0.094 \pm 0.002$, $0.104 \pm 0.002, * * 0.109 \pm 0.002 * *$ and $0.118 \pm 0.003 * * * \mathrm{mg} \mathrm{mL}^{-1}$, respectively, and $18 \mathrm{C} 6$ crown ethers at 1, 10, 20 and $30 \mathrm{mg} \mathrm{mL}^{-1}$ all enhanced riboflavin solubility to $0.095 \pm 0.003,0.100 \pm$ 
$0.003,0.113 \pm 0.003$ and $0.115 \pm 0.003 \mathrm{mg} \mathrm{mL}^{-1}$, respectively. $* * \quad * P<0.05 * * P<0.005$ $* * * P<0.001$, one way ANOVA, $n=3$.

From the HPLC results, phase solubility analysis was carried out using the methods developed by Higuchi and Conners $(1965)^{38}$ and reported by Jarho et al. (1996). ${ }^{31}$ Phase solubility plots were produced for mmol L-1 concentrations of the crown ether standards and their corresponding mmol L ${ }^{-1}$ riboflavin concentration, Figure 1. 

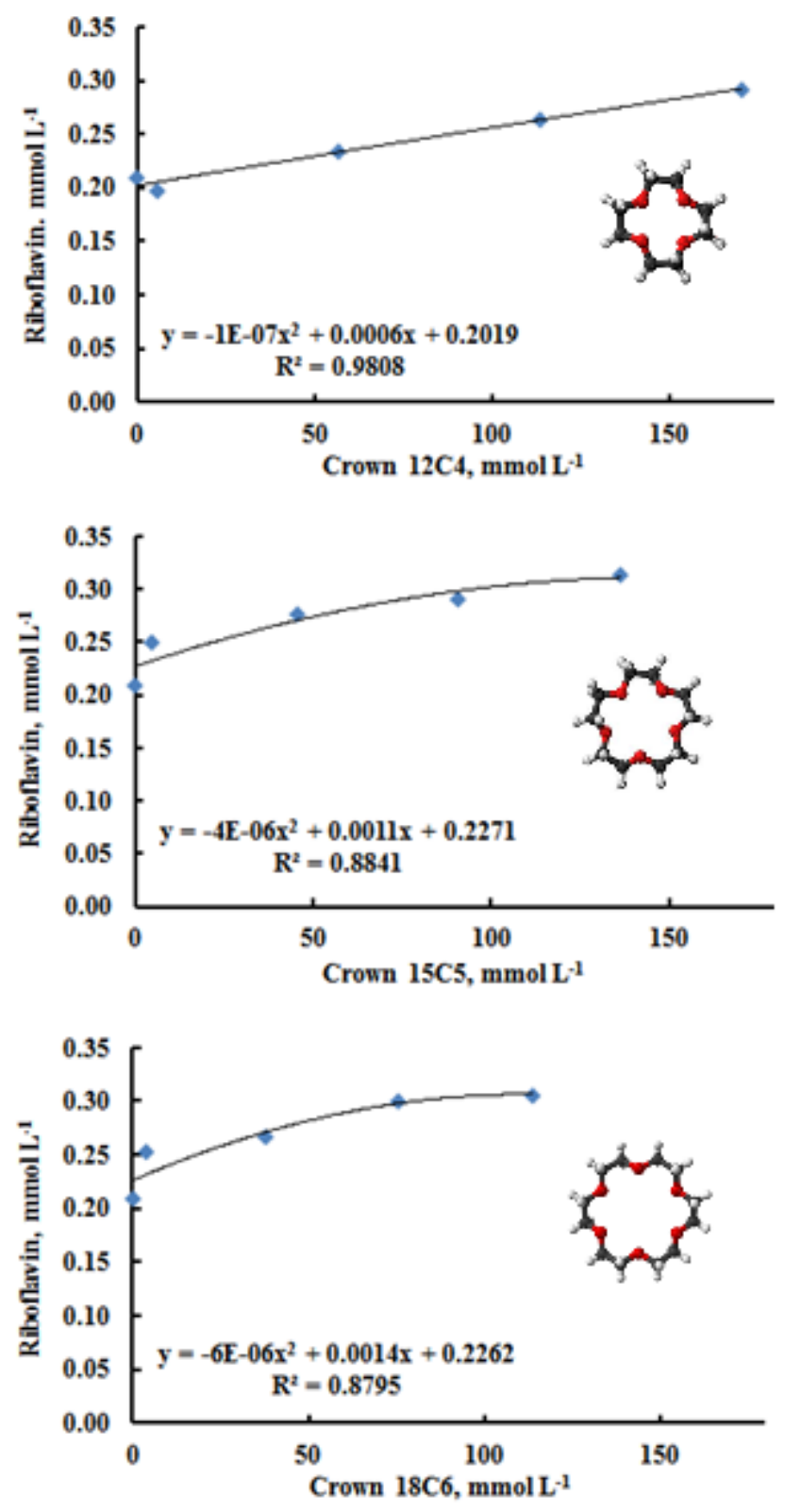

Figure 1 Phase solubility plots for riboflavin / crown ether. Inserts show the structures of 12C4, $15 \mathrm{C} 5$ and $18 \mathrm{C} 6$.

Crown ether / riboflavin association constants $K_{a: b}$ were calculated using Equation 1, and riboflavin solubility enhancement relative to its intrinsic aqueous solubility calculated using 
Equation 2. It should be noted that the phase solubility plots for riboflavin with 15C5 and $18 \mathrm{C} 6$ are not linear, which introduces some inaccuracy in determination of $\mathrm{K}_{\mathrm{a}: \mathrm{b}}$ compared to $12 \mathrm{C} 4$. At $1 \mathrm{mg} \mathrm{mL}-1$ crown ether reduced riboflavin solubility by $-9 \%$ using $12 \mathrm{C} 4 * *$ and enhanced riboflavin solubility by $16 \%$ for $15 \mathrm{C} 5^{* *}$ and $17 \%$ for $18 \mathrm{C} 6^{* *}$ and at $30 \mathrm{mg} \mathrm{mL}^{-1}$ they enhanced riboflavin solubility by $36 \%$ for $12 \mathrm{C} 4{ }^{* *} 46 \%$ for $15 \mathrm{C} 5 * * *$ and $42 \%$ for $18 \mathrm{C} 6{ }^{* * *}$ Table 1 lists the concentrations of riboflavin in the various crown ether solutions together with the corresponding association constants and riboflavin solubility enhancement as a percentage relative to riboflavin in deionised water.

Table 1 Crown ether / riboflavin association constant and enhanced solubility compared to riboflavin in de-ionized water.

\begin{tabular}{cccc}
$\begin{array}{c}\text { Crown ether / } \\
\text { riboflavin solution }\end{array}$ & $\begin{array}{c}\text { Riboflavin } \\
\text { mg mL } \mathbf{L}^{-1}\end{array}$ & $\begin{array}{c}\text { Association constant } \\
\boldsymbol{K}_{\text {crown:RF }} \mathbf{M}^{-1}\end{array}$ & $\begin{array}{c}\text { Riboflavin solubility } \\
\text { enhancement \% }\end{array}$ \\
\hline $12 \mathrm{C} 4\left(1 \mathrm{mg} \mathrm{mL}^{-1}\right)$ & $0.074 \pm 0.003$ & 2.39 & $-9 * *$ \\
$15 \mathrm{C} 5\left(1 \mathrm{mg} \mathrm{mL}^{-1}\right)$ & $0.094 \pm 0.002$ & 2.87 & $17 * *$ \\
$18 \mathrm{C} 6\left(1 \mathrm{mg} \mathrm{mL}^{-1}\right)$ & $0.095 \pm 0.003$ & 3.35 & $36 * *$ \\
$12 \mathrm{C} 4\left(30 \mathrm{mg} \mathrm{mL}^{-1}\right)$ & $0.110 \pm 0.004$ & 2.39 & $46 * * *$ \\
$15 \mathrm{C} 5\left(30 \mathrm{mg} \mathrm{mL}^{-1}\right)$ & $0.118 \pm 0.003$ & 2.87 & $42 * * *$ \\
$18 \mathrm{C} 6\left(30 \mathrm{mg} \mathrm{mL}^{-1}\right)$ & $0.115 \pm 0.003$ & 3.35 & \\
\hline$* * P<0.005, * * * P<0.001$, one way ANOVA, $n=3$. &
\end{tabular}


The trend shows that crown ethers have increasing riboflavin binding affinity and solubility enhancing properties as the molecule size increases. Complex formation depends on the relative size of the host cavity and the guest molecule. ${ }^{15,16,39,40}$ Riboflavin is too large to reside within the cavity of any of the crown ethers investigated in this study, ${ }^{28}$ however partial complexation is possible and more likely with the larger molecular variants and this could reasonably explain the increasing solubility of riboflavin as larger crown ethers are used. Further studies of the nature of the complexation between crown ethers and riboflavin could potentially be conducted using other techniques, e.g. NMR spectroscopy, but this is outside of the scope of the present work.

\section{Isothermal titration calorimetry analysis of crown ether / $\mathrm{Ca}^{2+}$}

ITC was used to determine $\mathrm{Ca}^{2+}$ binding efficiency of $5 \mathrm{mM} 12 \mathrm{C} 4,15 \mathrm{C} 5$ and $18 \mathrm{C} 6$ solutions at physiological $\mathrm{pH}$ 7.4. Figure 2 shows individual raw data and corresponding isotherms of the respective compounds titrated with $\mathrm{CaCl}_{2}$. Fitting of the isotherm curves is poorer for crown ethers in comparison with other chelating agent reported by us in a previous study, ${ }^{15}$ evident by the lack of any distinct transition seen in the isotherms. 

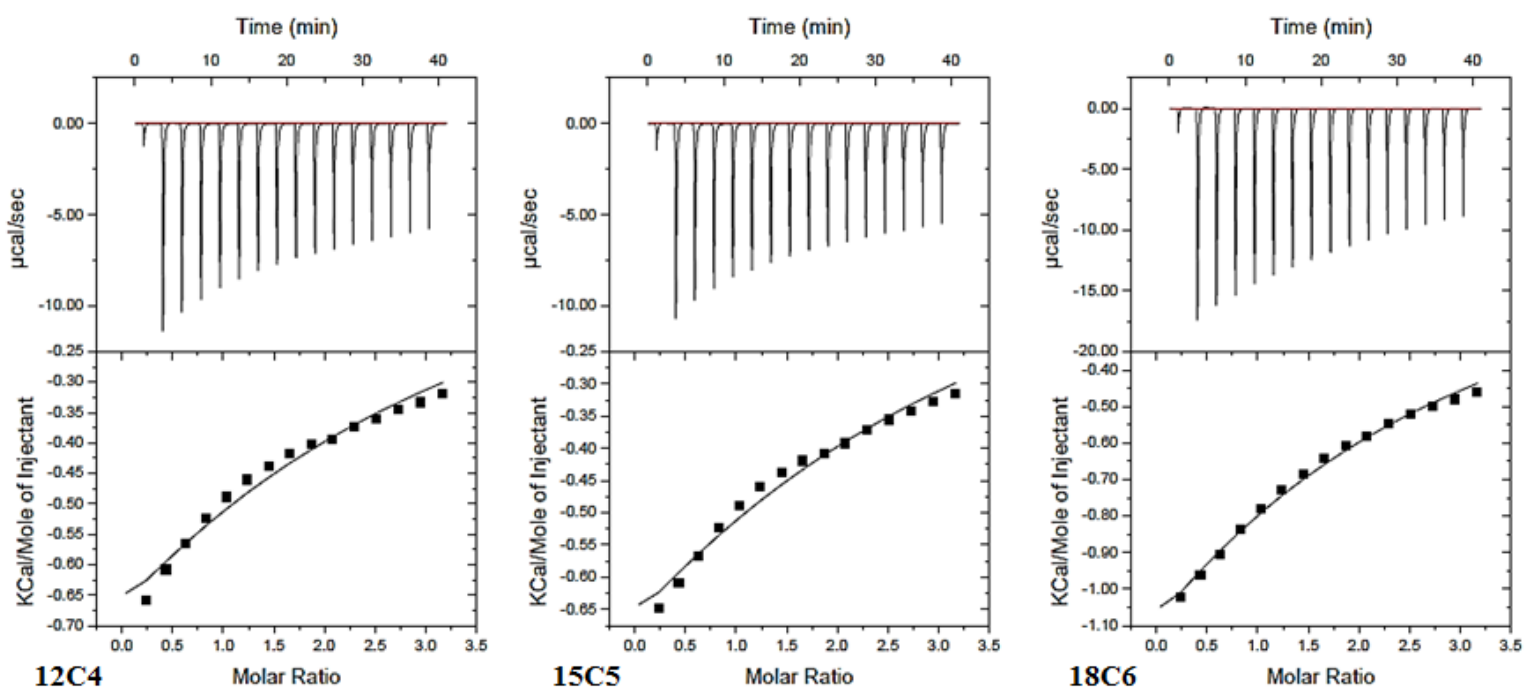

Figure 2 Isotherms for $\mathrm{Ca}^{2+}$ titration of $5 \mathrm{mmol} 12 \mathrm{C} 4,15 \mathrm{C} 5$ and $18 \mathrm{C} 6$ crown ether solutions titrated using $100 \mathrm{mmol} \mathrm{CaCl}_{2}$.

Measured values of enthalpy $(\Delta H)$, stoichiometry $(N)$, binding affinity $\left(K_{b}\right)$ and entropy $(\Delta S)$ from this analysis are shown in Table 2

Table 2 ITC analysis at pH $7.4 \pm 0.2$ of $12 \mathrm{C} 4,15 \mathrm{C} 5$ and $18 \mathrm{C} 6$ crown ethers titrated with $\mathrm{CaCl}_{2}$.

\begin{tabular}{|c|c|c|c|c|c|}
\hline Chelator in & $\mathrm{CaCl}_{2}$ in & Stoichiometry & Binding affinity & $\Delta H$ & $\Delta S$ \\
\hline $10 \mathrm{mM}$ MES & 10 mM MES & {$[N]$} & {$\left[K_{b}\right]\left(\mathbf{M}^{-1}\right)$} & $\left(\mathrm{kJ} \mathrm{mol}^{-1}\right)$ & $\left(\mathrm{J} \mathrm{mol}{ }^{-1} \mathrm{deg}^{-1}\right)$ \\
\hline $12 \mathrm{C} 4(5 \mathrm{mM})$ & $100 \mathrm{mM}$ & $1.99 \pm 0.06$ & $4.47 \pm 1.37$ & $-2.50 \pm 0.22$ & $-0.89 \pm 0.18$ \\
\hline $15 \mathrm{C} 5(5 \mathrm{mM})$ & $100 \mathrm{mM}$ & $2.43 \pm 0.03$ & $4.36 \pm 1.02$ & $-1.84 \pm 0.06$ & $1.32 \pm 0.22$ \\
\hline $18 \mathrm{C} 6(5 \mathrm{mM})$ & $100 \mathrm{mM}$ & $1.60 \pm 0.07$ & $4.20 \pm 3.20$ & $-4.11 \pm 0.24$ & $-6.35 \pm 0.91$ \\
\hline
\end{tabular}


There is a strong interest of researchers in the studies of complexation between crown ethers and various cations. ${ }^{41-43} \mathrm{~A}$ number of studies has been published on the analysis of complexation thermodynamics in these systems. Many of these studies were conducted using organic solvents, which is not relevant to interactions in biological systems. There is also lack of studies of the complexation between crown ethers and calcium ions in aqueous media. Izatt et $a{ }^{44}$ have used calorimetric titration procedure to study the $1: 1$ reactions between 15 -crown- 5 and 18 -crown- 6 and several uni- and bivalent cations at $25{ }^{\circ} \mathrm{C}$ in aqueous solutions. However, they did not record any measurable heat effects for the complexation of $15 \mathrm{C} 5$ with $\mathrm{Ca}^{2+}$ and observed only

very weak interactions between $18 \mathrm{C} 6$ and $\mathrm{Ca}^{2+}$. Solov'ev et al ${ }^{45}$ later used solution calorimetry and ${ }^{43} \mathrm{Ca}$ NMR spectroscopy to study the thermodynamics of the complexation of $18 \mathrm{C} 6$ with calcium chloride and nitrate in aqueous solutions in a broad range of concentrations. They reported $\Delta \mathrm{H}$ and $\Delta \mathrm{S}$ values of $\mathrm{CaCl}_{2}$ complexation with $18 \mathrm{C} 6$ to be $-9.44 \pm 2.18 \mathrm{~kJ} \mathrm{~mol}^{-1}$ and $22.9 \pm 7.3 \mathrm{~J} \mathrm{~mol}^{-1} \mathrm{~K}^{-1}$, which is greater compared to the values observed in our work. The discrepancy between our results and the data reported by Solov'ev et al ${ }^{45}$ could be due to the difference in the calorimetric equipment and protocols used in both studies.

\section{$\mathrm{Ca}^{2+}$ extraction from bovine cornea using crown ethers}

Crown ethers are known for their ability to sequester metal ions, the efficiency of this effect depends on many factors, for example, cavity size, enthalpy and $\mathrm{pH}^{39,40}$ Smaller metal ions deform the chelate ring to make interactions stronger between the metal ion and oxygen atoms within the molecule, whilst larger ions reside close to but outside the cavity. ${ }^{15}$ Here, the ability of $12 \mathrm{C} 4,15 \mathrm{C} 5$ and $18 \mathrm{C} 6$ crown ether solutions to extract $\mathrm{Ca}^{2+}$ ions from bovine cornea was investigated using atomic absorption spectrometry. Using the 'whole eye method', ${ }^{28} 1 \mathrm{~mL}$ of 20 
$\mathrm{mg} \mathrm{mL}^{-1}$ solutions of $12 \mathrm{C} 4,15 \mathrm{C} 5$ and $18 \mathrm{C} 6$ crown ethers in $\mathrm{PBS}$ at $\mathrm{pH} 7.4 \pm 0.2$ were exposed to an area of bovine cornea $\left(1.54 \pm 0.22 \mathrm{~cm}^{2}\right)$ for 3 hours. Three fresh eyes were used for each crown ether solution and after exposure the solutions were recovered, centrifuged for 10 minutes at $10000 \mathrm{rpm}$ and the supernatant was diluted in $0.25 \mathrm{w} / \mathrm{v}$ aqueous $\mathrm{LaCl}_{3}$ solution for AAS analysis. This investigation has shown that PBS has the ability to absorb $\mathrm{Ca}^{2+}$ ions and this is likely to be due to dissolving soluble mucins from the ocular surface. Crown ethers are able to sequester $\mathrm{Ca}^{2+}$ from the cornea above this 'background' level. ${ }^{46}$ Figure 3 shows differences in calcium content of solutions before corneal exposure compared to the same solutions after exposure to the cornea. All formulations show a net increase in $\mathrm{Ca}^{2+}$ concentration at the end of this experiment and the rank order of calcium sequestering performance from bovine cornea compared to PBS is; PBS $(54.67 \pm 7.04 \mathrm{ppm})<12 \mathrm{C} 4 * *(62.58 \pm 1.10 \mathrm{ppm})<15 \mathrm{C} 5 * *(69.42 \pm$ $0.65 \mathrm{ppm})<18 \mathrm{C} 6 *(81.39 \pm 1.38 \mathrm{ppm}) . * P<0.05, * * P<0.01, * * * P<0.001$, one-way ANOVA, $n=3$.

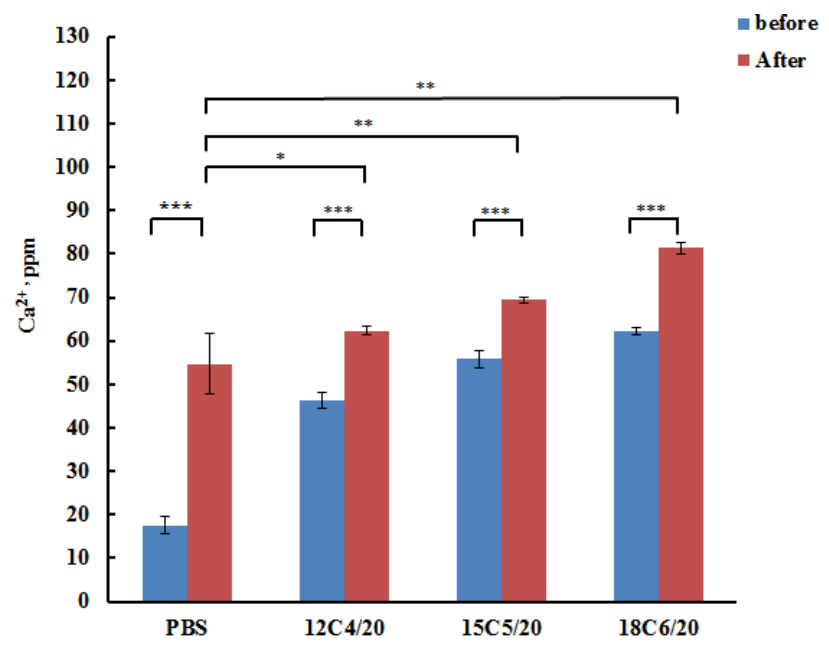


Figure $3 \mathrm{Ca}^{2+}$ concentration in solutions of crown ethers $\left(20 \mathrm{mg} \mathrm{mL}^{-1}\right)$ in PBS before and after 3 hours exposure to bovine cornea. $* P<0.05$, ** $P<0.01$, *** $P<0.001$, one way ANOVA, $\mathrm{n}=$ 3.

\section{Effect of crown ethers on permeability of riboflavin through bovine cornea}

In vitro studies using Franz diffusion cells were carried out to investigate any permeability enhancement of riboflavin using crown ethers. The receiving chamber was filled with PBS at physiological $\mathrm{pH}(16.5 \mathrm{~mL})$ and $1 \mathrm{~mL}$ of each crown ether solution in PBS incorporating 0.08 $\mathrm{mg} \mathrm{mL}^{-1}$ riboflavin was added to the epithelial side of the cornea. $200 \mu \mathrm{L}$ aliquots were taken for HPLC analysis every 60 minutes for 240 minutes. Experiments were carried out in triplicate and analysis was carried out at the time of sampling to prevent sample degradation. Results are reported as the mean \pm standard deviation. Statistical analysis by ANOVA was applied and $P$ values $<0.05$ were considered significant. Figure 4a shows the overlaid riboflavin permeability profiles for crown ethers at $1 \mathrm{mg} \mathrm{mL}^{-1}$, Figure 4b shows the graphs for crown ethers at $30 \mathrm{mg}$ $\mathrm{mL}^{-1}$, error bars have not been included for clarity. The same profiles are shown individually with error bars in supporting information (Figure S1). The results show that $12 \mathrm{C} 4$, $15 \mathrm{C} 5$ and $18 \mathrm{C} 6$ crown ethers at $1 \mathrm{mg} \mathrm{mL}^{-1}$ all afford a moderate enhancement in riboflavin permeability across bovine cornea to $22 \pm 6,19 \pm 7$ and $14 \pm 4 \mathrm{ng} \mathrm{mL}^{-1}$ at 240 minutes respectively compared to riboflavin in PBS which is $8 \pm 2 \mathrm{ng} \mathrm{mL}^{-1}$, whilst at $30 \mathrm{mg} \mathrm{mL}^{-1}$ they offer a significant enhancement at $62 \pm 23,35 \pm 4$ and $33 \pm 7 \mathrm{ng} \mathrm{mL}^{-1}$ respectively. There is no significant difference in riboflavin permeability enhancement between the different crown ethers except for the difference between $12 \mathrm{C} 4$ and $18 \mathrm{C} 6$ at $30 \mathrm{mg} \mathrm{mL}^{-1}$. 
Apparent permeability and steady state flux were calculated using Equation $\mathbf{3}$ and the results are given in Table 3.

Table 3 Steady state flux and apparent permeability of riboflavin through bovine cornea in PBS with and without crown ether.

\begin{tabular}{|c|c|c|}
\hline Solution & 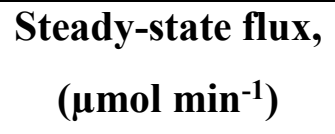 & $\begin{array}{c}\mathbf{P}_{\text {app }} \\
\left(\mathrm{cm} \mathrm{s}^{-1} \times 10^{-3}\right)\end{array}$ \\
\hline PBS & 0.0478 & 1.945 \\
\hline $12 \mathrm{C} 41 \mathrm{mg} \mathrm{mL}^{-1}$ & 0.1208 & 6.138 \\
\hline $15 \mathrm{C} 51 \mathrm{mg} \mathrm{mL}^{-1}$ & 0.1074 & 5.457 \\
\hline $18 \mathrm{C} 61 \mathrm{mg} \mathrm{mL}^{-1}$ & 0.0753 & 3.826 \\
\hline $12 \mathrm{C} 430 \mathrm{mg} \mathrm{mL}^{-1}$ & 0.341 & 17.326 \\
\hline $15 \mathrm{C} 530 \mathrm{mg} \mathrm{mL}^{-1}$ & 0.1961 & 9.964 \\
\hline $18 \mathrm{C} 630 \mathrm{mg} \mathrm{mL}^{-1}$ & 0.1811 & 9.202 \\
\hline
\end{tabular}



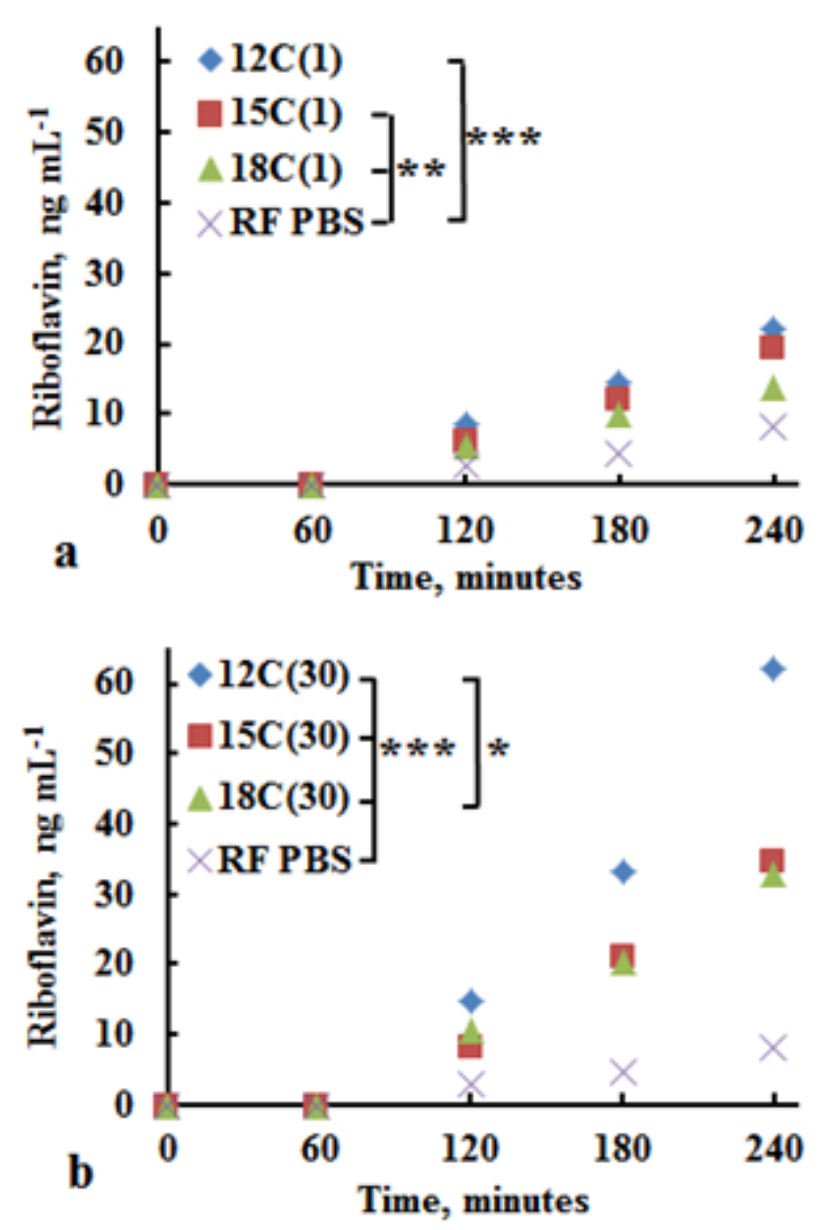

Figure 4 Permeability profiles for riboflavin in crown ether / PBS solutions through bovine cornea. Crown ethers at $1 \mathrm{mg} \mathrm{mL}^{-1}$ (a), $30 \mathrm{mg} \mathrm{mL}^{-1}$ (b) * $P<0.05$, ** $P<0.01$, *** $P<0.001$, one way ANOVA, $\mathrm{n}=3$.

Comparing riboflavin permeability enhancing performance between crown ethers and polyaminocarboxylic acids at the same concentration $\left(1 \mathrm{mg} \mathrm{mL}^{-1}\right)$ and with riboflavin concentration at $0.08 \mathrm{mg} \mathrm{mL}^{-1}$ it has been shown that crown ethers have superior permeability enhancing properties (Table 4). The smallest crown ether molecular variant offered the best performance. 
Table 4 Bovine cornea permeation of riboflavin using polyaminocarboxylic acids and crown ethers.

\begin{tabular}{cc}
\hline Enhancer, $\mathbf{1} \mathbf{~ m g ~ m L}^{-1}$ & Riboflavin, $\boldsymbol{\mu m o l}$ \\
\hline EDTA & $0.032 \pm 0.007$ \\
EGTA & $0.035 \pm 0.004$ \\
EDDS & $0.025 \pm 0.010$ \\
12C4 & $0.059 \pm 0.016$ \\
15C5 & $0.052 \pm 0.018$ \\
18C6 & $0.036 \pm 0.011$ \\
\hline
\end{tabular}

\section{Effect of crown ethers on riboflavin penetration into bovine cornea}

When treating corneal disorders such as keratoconus, it is essential that riboflavin is taken up by the stroma where UVA collagen cross-linking is facilitated. ${ }^{5}$ Therefore, crown ether mediated riboflavin transport into the cornea was evaluated.

Corneas from the above diffusion studies were trimmed to exclude limbal and scleral tissue. Riboflavin was extracted using absolute ethanol with subsequent analysis using HPLC. It was found that all the crown ethers investigated enhanced corneal absorption of riboflavin significantly greater than riboflavin in PBS alone. At $1 \mathrm{mg} \mathrm{mL}^{-1}$ there was an increasing concentration of riboflavin extract from the corneas; $0.470 \pm 0.003 \mathrm{ng} \mathrm{mg}^{-1}$ for $12 \mathrm{C} 4, * * * 0.930$ $\pm 0.145 \mathrm{ng} \mathrm{mg}^{-1}$ for $15 \mathrm{C} 5 * * *$ and $1.450 \pm 0.182 \mathrm{ng} \mathrm{mg}^{-1}$ for $18 \mathrm{C} 6{ }^{* *}$ At $30 \mathrm{mg} \mathrm{mL}^{-1}$ there was a further increase in riboflavin extract, however the trend reversed with the highest concentration for $12 \mathrm{C} 4$ at $1.790 \pm 0.245 \mathrm{ng} \mathrm{mg}^{-1 * * *}$, reducing to $1.510 \pm 0.164 \mathrm{ng} \mathrm{mg}^{-1}$ for $15 \mathrm{C} 5 * * *$ and to 
$1.00 \pm 0.1975 \mathrm{ng} \mathrm{mg}^{-1}$ for $18 \mathrm{C} 6 .^{* * *}$ Table 5 lists the amounts of riboflavin extracted from bovine corneas after exposure to PBS with and without crown ether after 4 hours exposure. ${ }^{*} P$ $<0.05, * * P<0.01, * * * P<0.001$, one way ANOVA, $\mathrm{n}=3$.

Table 5 Riboflavin extracted from treated corneas after 4 hours exposure, $\mathrm{ng} \mathrm{mg}^{-1}$.

\begin{tabular}{|c|c|}
\hline $\begin{array}{l}\text { Crown ether solution in PBS } \\
\text { with } 0.08 \mathrm{mg} \mathrm{mL}^{-1} \text { riboflavin }\end{array}$ & $\begin{array}{c}\text { Riboflavin, } \\
\text { ng mg }^{-1} \text { cornea }\end{array}$ \\
\hline$\overline{\mathrm{PBS}}$ & $0.060 \pm 0.001$ \\
\hline $12 \mathrm{C} 41 \mathrm{mg} \mathrm{mL}^{-1}$ & $0.470 \pm 0.003^{* * *}$ \\
\hline $15 \mathrm{C} 51 \mathrm{mg} \mathrm{mL}^{-1}$ & $0.930 \pm 0.145^{* * *}$ \\
\hline $18 \mathrm{C} 61 \mathrm{mg} \mathrm{mL}^{-1}$ & $1.450 \pm 0.182^{* *}$ \\
\hline $12 \mathrm{C} 430 \mathrm{mg} \mathrm{mL}^{-1}$ & $1.790 \pm 0.245^{* * *}$ \\
\hline $15 \mathrm{C} 530 \mathrm{mg} \mathrm{mL}^{-1}$ & $1.510 \pm 0.164^{* * *}$ \\
\hline $18 \mathrm{C} 630 \mathrm{mg} \mathrm{mL}^{-1}$ & $1.000 \pm 0.198^{* * *}$ \\
\hline
\end{tabular}

\section{Toxicological investigation}

Epithelial damage is linked to corneal opacity and this phenomenon can be indicative of a substances ocular toxicity. Figure 5 shows that the three different crown ethers, 12C4, 15C5 and 18C6, produce a similar level of epithelial change, and increasing the concentration from $1 \mathrm{mg}$ 
$\mathrm{mL}^{-1}$ to $30 \mathrm{mg} \mathrm{mL}^{-1}$ does not increase induced opacity. The level of epithelial damage caused by crown ethers was similar to that caused by the various concentrations of the BAC compounds and was much lower compared with the positive controls, $\mathrm{NaOH} 0.5 \mathrm{M}$ and $1.0 \mathrm{M}$, which display a high level of corneal opacity due to alkali burning. BAC is often used in ocular formulations in concentrations up to $0.02 \%$ to act as a penetration enhancer and preservative. ${ }^{47}$ At higher concentration BAC is known to be an irritant and toxic. ${ }^{48}$

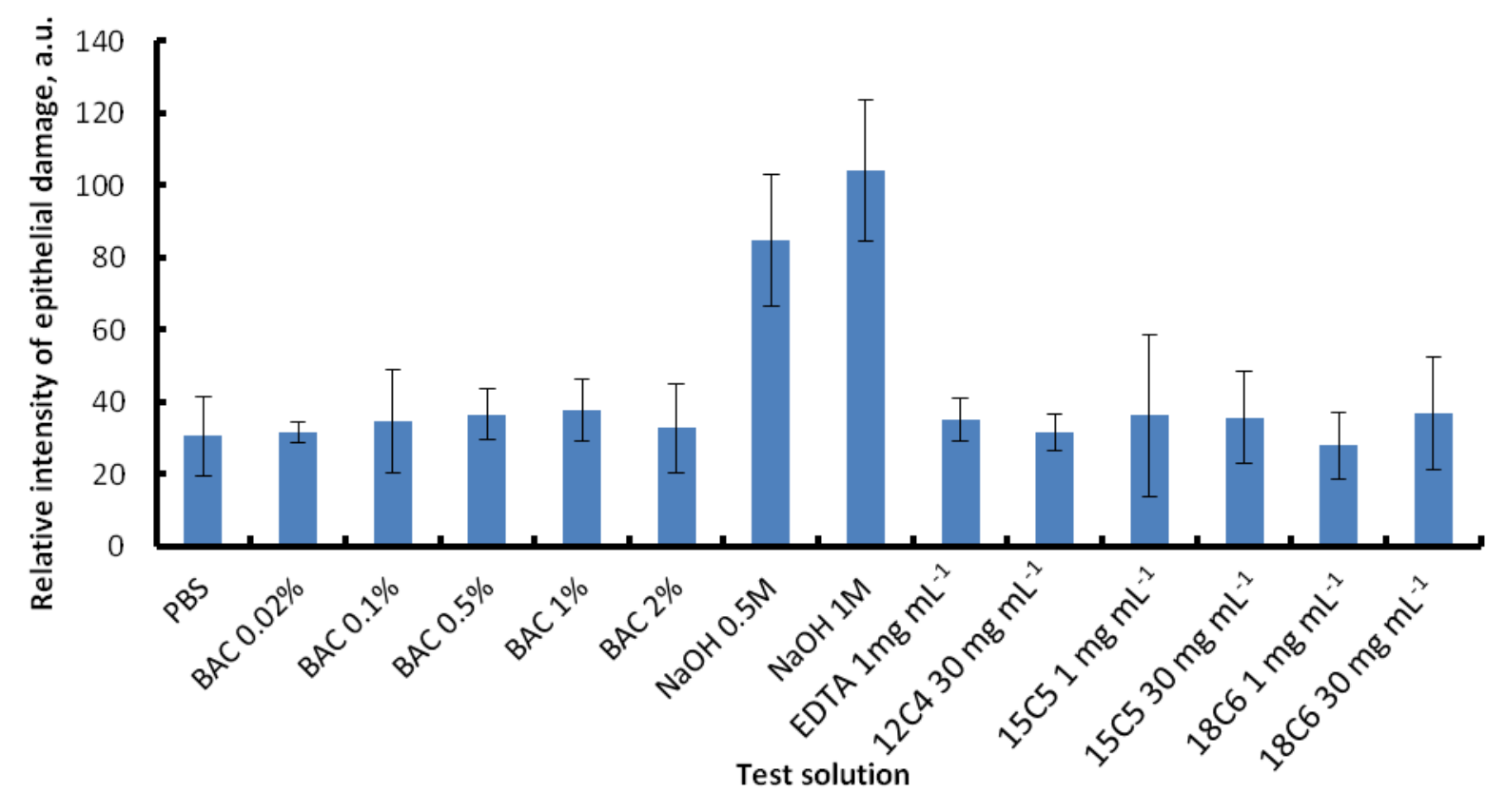

Figure 5 Relative intensity of epithelial damage caused by PBS (negative control), BAC $0.02 \%$, BAC $0.1 \%$, BAC $0.5 \%$, BAC $1 \%$, BAC $2 \%, \mathrm{NaOH} 0.5 \mathrm{M}$, (positive control) $\mathrm{NaOH} 1 \mathrm{M}$, positive control) EDTA $1 \mathrm{mg} \mathrm{mL}^{-1}, 12 \mathrm{C} 430 \mathrm{~g} \mathrm{~mL}^{-1}, 15 \mathrm{C} 51$ and $30 \mathrm{mg} \mathrm{mL}^{-1}$ and $18 \mathrm{C} 61$ and $30 \mathrm{mg} \mathrm{mL}^{-1}$. No significant difference between all tested compounds except for the positive controls which showed a significantly damaging effect on bovine cornea epithelia. ${ }^{* * *} \quad * * * P<0.001$, one way ANOVA, $\mathrm{n}=3$. 
Crown ethers display ionophoretic properties in cell membranes and behave similarly to natural ionophores, i.e. valinomycin, a cyclicdepsipeptide antibiotic. ${ }^{22,49}$ Therefore, their toxic effect is thought to be due to penetration of the cellular bilayer membrane ${ }^{50}$ By applying these compounds to the cornea, epithelial disruption allows for permeation of fluorescein dye. Figure 6 shows that the fluorescent intensity of epithelial surfaces treated with the crown ethers is comparable to corneas treated with $\mathrm{BAC} 1 \%$ and $2 \%{ }^{*}$ High permeation of the fluorescein dye shows that if the permeability enhancer was to be used in conjunction with a therapeutic compound such as riboflavin in eye drop formulations, it would afford assisted transport into the cornea and could eliminate the need for invasive epithelial removal. Comparing crown ethers with $\mathrm{BAC}$ in the concentrations shown suggests they appear to be more toxic than $\mathrm{BAC}$ at the accepted level $(0.02 \%)^{*}$ used in many eye drop formulations, but less toxic than BAC concentrations $>0.1 \%$ and EDTA at $1 \mathrm{mg} \mathrm{mL}^{-1}$, especially for the $12 \mathrm{C} 4$ variant. The positive controls $0.5 \mathrm{M} \mathrm{NaOH}$ and $1.0 \mathrm{M} \mathrm{NaOH}$ were significantly more toxic than all other compounds tested.*** $* P<0.05, * * P<0.01, * * * P<0.001$, one way ANOVA, $\mathrm{n}=3$. 


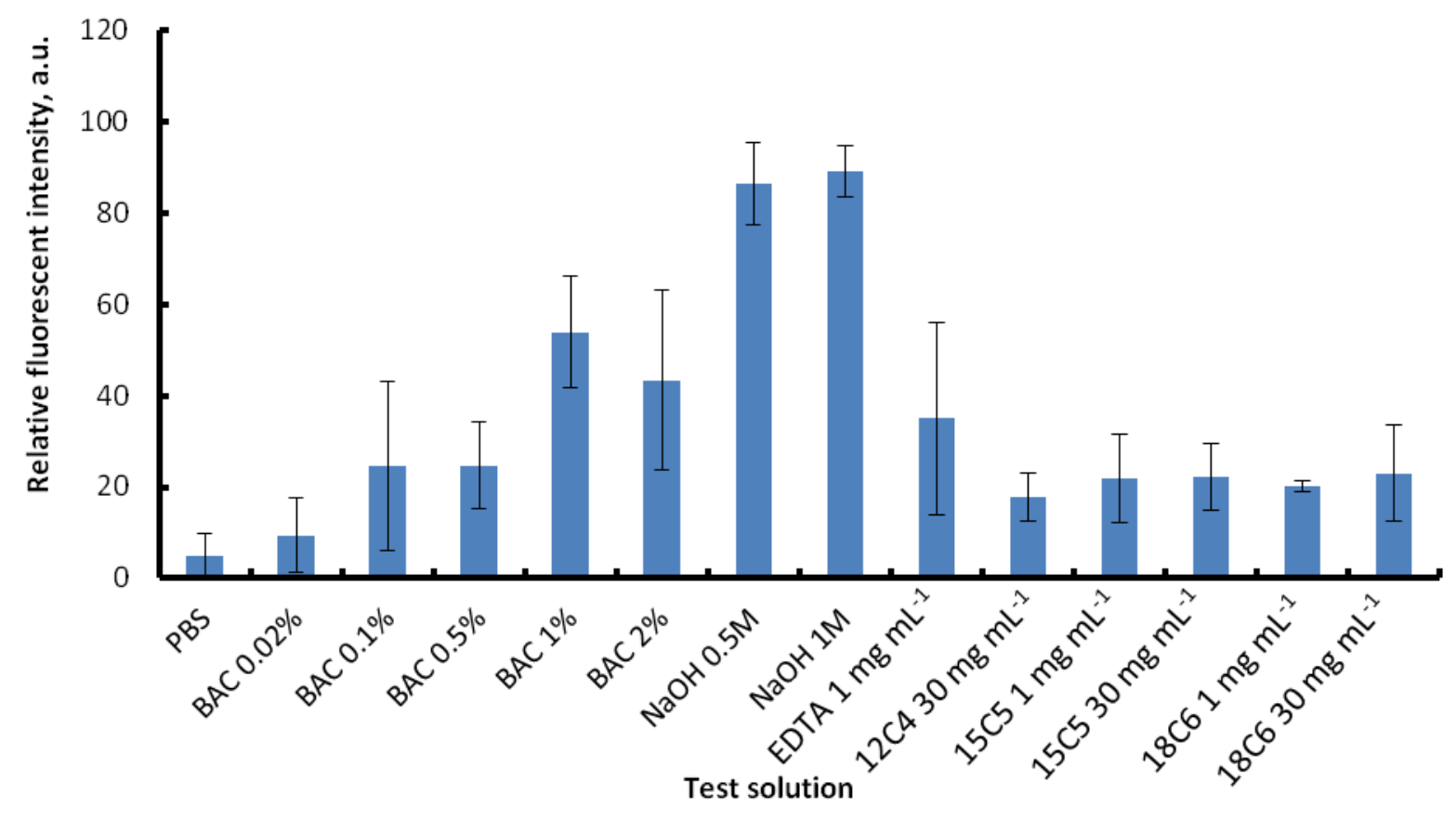

Figure 6 Fluorescent intensity of epithelial surface pre-treated with PBS, BAC $0.02 \%$ to $2.0 \%$, EDTA $1 \mathrm{mg} \mathrm{mL}^{-1}, \mathrm{NaOH} 0.5 \mathrm{M}$ and $1.0 \mathrm{M}$ and crown ether between 1 and $30 \mathrm{mg} \mathrm{mL}^{-1}$, followed with fluorescein sodium staining

\section{In vivo experiments}

In vivo experiments were conducted in Wistar rats $(n=3)$ to test ocular penetration of riboflavin using $0.08 \mathrm{mg} \mathrm{mL}^{-1}$ drug formulations with and without $30 \mathrm{mg} \mathrm{mL}^{-1} 12 \mathrm{C} 4$, the crown ether that demonstrated the best penetration enhancement performance in vitro. $2 \mathrm{~mL}$ of the drug formulations were instilled into both eyes gradually within 40 min (Figure S2). This timing was chosen to ensure the practicality of working with live animals and also to keep it relatively close to the drug administration procedure used clinically $\left(30 \mathrm{~min}^{5}\right)$.

Unfortunately, the results of these in vivo experiments did not show any statistically significant penetration enhancement effect with $30 \mathrm{mg} \mathrm{mL}^{-1} 12 \mathrm{C} 4$ : the amounts of riboflavin extracted from 
the eyes after the application of the formulations with and without $12 \mathrm{C} 4$ were $0.3889 \pm 0.0998$ and $0.4855 \pm 0.1702 \mu \mathrm{g} \mathrm{g} \mathrm{g}^{-1}$, respectively, and the difference between these values is not statistically significant $(\mathrm{p}>0.05)$.

Additional experiments were performed to evaluate the effect of riboflavin formulations with and without $30 \mathrm{mg} \mathrm{mL}^{-1} 12 \mathrm{C} 4$ on the epithelial morphology of rat corneas. Figure 7 shows the histological images of rat corneas, following in vivo administration of $1 \mathrm{~mL} 0.08 \mathrm{mg} \mathrm{mL} \mathrm{m}^{-1}$ riboflavin solutions with and without $30 \mathrm{mg} \mathrm{mL}^{-1} 12 \mathrm{C} 4$ during 40 mins. A comparison of the corneal morphology allows conclusions that the use of formulation containing $30 \mathrm{mg} \mathrm{mL}^{-1} 12 \mathrm{C} 4$ does not lead to any serious epithelial disruption. The epithelial cells remain intact and tightly attached to the stroma. Previously, we have reported the disruptive effects of cyclodextrins ${ }^{28}$ and chelating agents ${ }^{15}$ on the bovine corneas in vitro. However, we did not observe any similar disruptive effects in vivo.

Unfortunately, in vivo experiments did not provide any evidence for penetration enhancement effects caused by $12 \mathrm{C} 4$.

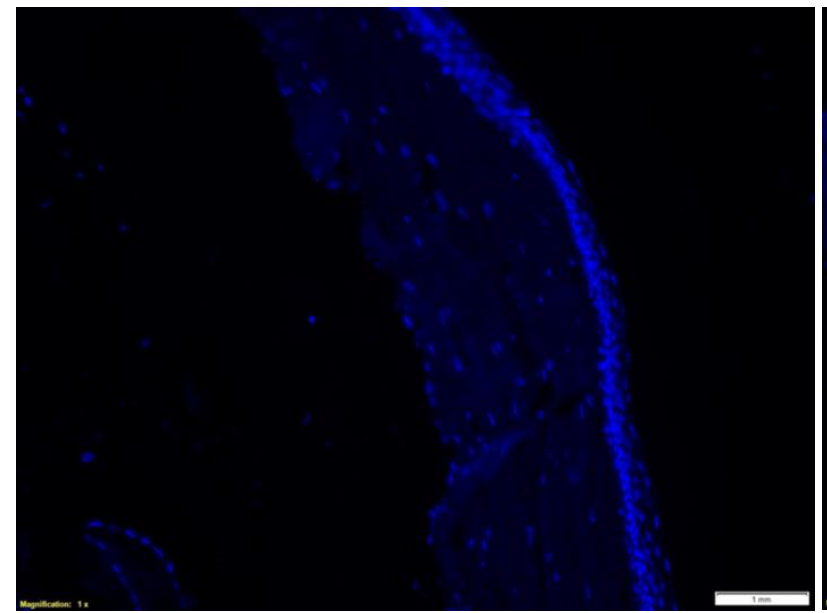

(a)

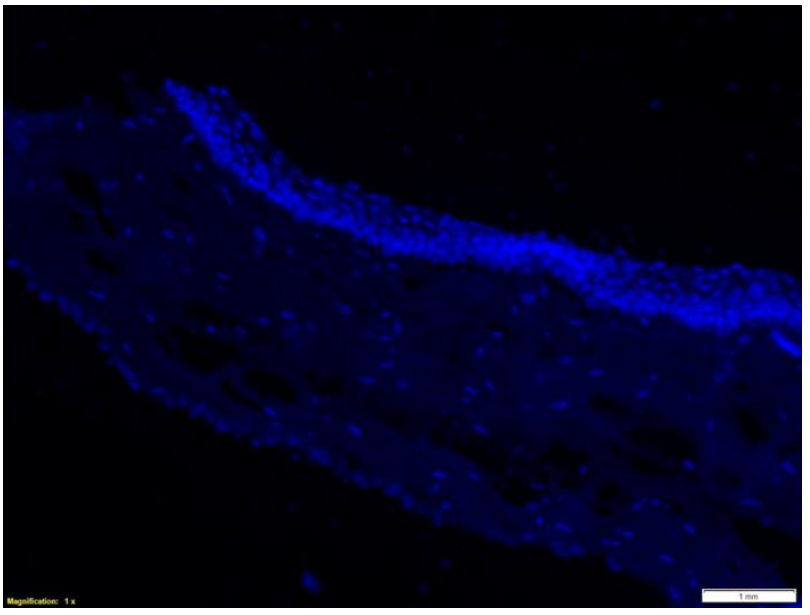

(b) 
Figure 7. Histology of rat corneas following in vivo administration of $1 \mathrm{~mL} 0.08 \mathrm{mg} \mathrm{mL}^{-1}$ riboflavin solution without (a) and with (b) $30 \mathrm{mg} \mathrm{mL}^{-1} 12 \mathrm{C} 4$ during 40 mins. Scale bar is 100 $\mu \mathrm{m}$.

The possible reason for this lack of in vitro - in vivo correlation is the dynamic nature of live corneal surfaces that are continuously washed with a tear fluid. During in vitro experiments the riboflavin formulations containing crown ethers as penetration enhancers clearly exhibited better drug penetration because of the static nature of bovine corneas, giving a possibility for their prolonged contact with a biological surface. In vivo the situation is very much different and the enhancer is quickly washed off the ocular surface. To test this hypothesis, we have conducted additional experiments on fluorescein retention on rat's cornea in vivo. $1 \mathrm{mg} \mathrm{mL} \mathrm{mL}^{-1}$ sodium fluorescein solution was administered on rat's cornea and UV light was briefly shone into their eye to improve its detection, which under these conditions showed green fluorescence. Digital images were taken at different time intervals and some exemplary images are shown in Figure 8.

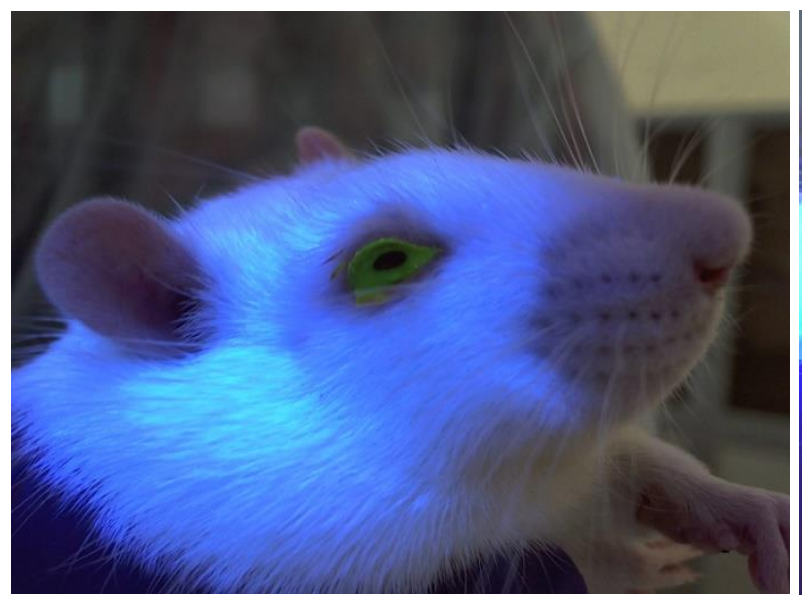

$0 \min$

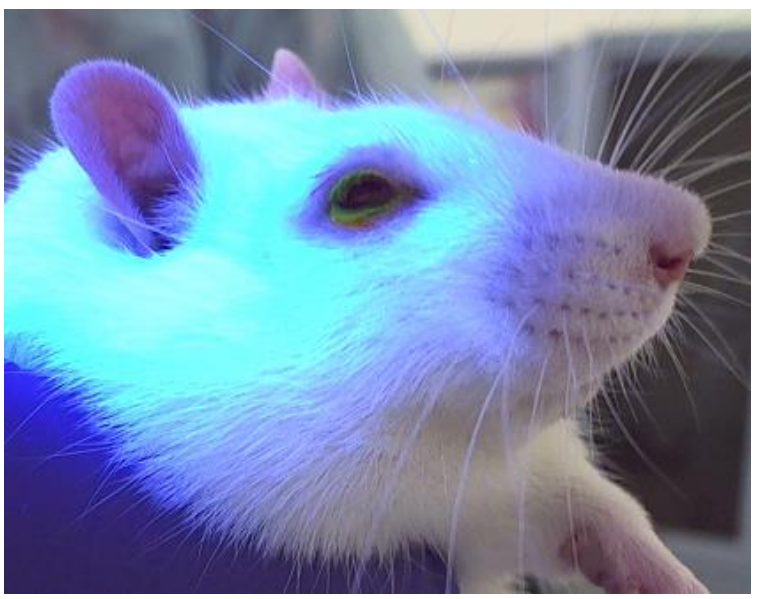

$5 \min$ 
Figure 8. Retention of $1 \mathrm{mg} \mathrm{mL} \mathrm{m}^{-1}$ sodium fluorescein on rat's cornea in vivo. UV light was shone to the eye to facilitate the detection of green fluorescence from sodium fluorescein.

It is clearly seen that sodium fluorescein is quickly washed off the corneal surface even within 5 minutes after ocular administration. This correlates well with our recent report on in vivo retention of fluorescein on rabbit corneas in vivo: non-viscous formulations containing fluorescein stayed on the corneal surfaces only for a few minutes. ${ }^{51}$ This lack of in vitro - in vivo correlation clearly highlights the need for further in vivo experiments in this area. The majority of in vitro models used to study drug retention / penetration into the ocular tissues are quite limited and cannot fully mimic the complex physiology of the ocular environment.

\section{Conclusions}

Crown ethers were investigated for their riboflavin solubility enhancing properties which could improve the drugs bioavailability. It was found that $12 \mathrm{C} 4$ at $1 \mathrm{mg} \mathrm{mL}^{-1}$ offered a slight reduction to the solubility of riboflavin whilst $15 \mathrm{C} 5$ and $18 \mathrm{C} 6$ at $1 \mathrm{mg} \mathrm{mL}^{-1}$ and all the investigated crown ethers at higher concentrations offered significant enhancement to riboflavin solubility, thereby increasing its availability for use in ocular drug formulations. Permeability enhancement of bovine corneas was investigated based on crown ethers ability to sequester metal ions, namely $\mathrm{Ca}^{2+}$, and on their ionophoric properties which could potentially improve drug transport across the physical barriers of the cornea. Riboflavin transport through bovine cornea was enhanced by all the crown ethers investigated and it was found that $12 \mathrm{C} 4$ was the most efficient at both concentrations tested $\left(1 \mathrm{mg} \mathrm{mL}^{-1}\right.$ and $\left.30 \mathrm{mg} \mathrm{mL}^{-1}\right)$, this could be due the size differences of the crown ether / drug complex. Crown ethers in PBS were found to significantly improve $\mathrm{Ca}^{2+}$ extraction from corneal epithelia compared to PBS alone; therefore they have the ability to 
loosen $\mathrm{Ca}^{2+}$ dependant tight junctions in the epithelial membrane. The permeability enhancing properties of crown ethers were shown to be superior compared to polyaminocarboxylic acids investigated in our previous study, ${ }^{15}$ however, it is concluded that crown ethers ionophoric properties enhance riboflavin permeability more than their $\mathrm{Ca}^{2+}$ sequestering properties. Further experiments determined that all the crown ether solutions investigated were efficient at delivering riboflavin into the corneal stroma and this is necessary for effective treatment following established UV ' $\mathrm{A}$ ' induced collagen cross linking for the treatment of keratoconus and other conditions of the cornea. Crown ethers are novel compounds which have not previously been investigated for ocular drug delivery prior to this study, therefore an assessment of potential toxicological implications of using crown ethers in ocular formulations was carried out and their toxicity was found to be of a similar level to BAC which is used as a preservative and penetration enhancer for eye drop medication. Crown ethers at $1 \mathrm{mg} \mathrm{mL}^{-1}$ and $30 \mathrm{mg} \mathrm{mL}^{-1}$ were shown to have lower epithelial toxicity than EDTA at $1 \mathrm{mg} \mathrm{mL}^{-1}$. This study has shown that crown ethers have an important role in development of ocular medications for improvement of drug solubility, enhanced drug penetration into the cornea and potential to eliminate the need for epithelial removal for treatment of corneal disorders.

Unfortunately, in vivo experiments performed in rats did not establish any significant enhancement in riboflavin permeation into the eye mediated with $30 \mathrm{mg} \mathrm{mL}^{-1} 12 \mathrm{C} 4$. The reason for this lack of permeability enhancement is the dynamic nature of live ocular tissue that is continuously washed with a tear fluid. Additional experiments with fluorescein confirmed that retention on the surface of the cornea in vivo is poor. Future research may look at the application of crown ethers in combination with mucoadhesive polymers to enhance both the drug permeability and pre-corneal retention. Another important finding from these experiments is a 
clear need for conducting in vivo experiments to evaluate the efficiency of a formulation to enhance corneal permeability of drugs. This work clearly demonstrated that experiments with ex vivo corneas could provide valuable information about drug permeation and permeability enhancement properties of different agents; however, this information is limited and cannot always predict the behaviour of a drug delivery system in vivo.

Further studies will be required to evaluate the potential of crown ethers to enhance corneal permeability for other drugs. Additionally, the studies where crown ethers are combined with mucoadhesive polymers to enhance drug permeation and to improve pre-corneal retention will be of interest. Our recent study of timolol maleate formulations ${ }^{52}$ demonstrated that the combination of permeability enhancers with some mucoadhesive polymers could potentially inhibit drug permeation through the cornea despite the improvements in pre-corneal retention, which indicates that there is still lack of understanding of permeability enhancement effects in multicomponent drug formulations.

\section{Acknowledgments}

The authors wish to thank the BBSRC for doctoral research funding (grant number: BB/F017189/1) and P. C Turners, Abattoirs, (Farnborough, UK) for the supply of fresh bovine eyes. VVK is grateful to the University of Reading for providing 2020 Research Fellowship grant and to the Ministry of Education and Science of the Republic of Tatarstan (Russia) for "Algarysh" grant to support his visits to Kazan State Medical University to conduct in vivo experiments. The authors are grateful to Dr Ekaterina G. Mikheeva and Mr Ramil Husnutdinov (Kazan State Medical University)) for help with histological experiments. The authors are also 
grateful to Prof Adrian C. Williams (University of Reading) for critical reading and valuable suggestions on improvement of this manuscript.

\section{SUPPORTING INFORMATION}

The Supporting Information is available free of charge on the ACS Publications website at xx. It includes images and numerical data from toxicological experiments, individual permeability profiles and image from in vivo experiments.

\section{References}

1. Kumaran, K. S. G. A.; Karthika, K.; Padmapreetha, J. Comparative Review on Conventional and Advanced Ocular Drug Delivery Formulations. Int. J. Pharm. Pharm. Sci. 2010, 2,1-5.

2. Abdulrazik, M.; Beher-Cohen, F.; Benita, S. Drug Delivery Systems for Enhanced Ocular Absorption. In: Enhancement in Drug Delivery, Touitou, E., Barry, B. W., Eds.; CRC Press: Florida, 2007; pp 489-525.

3. Washington, N.; Washington, C.; Wilson, C. G. Ocular Drug Delivery. In Physiological Pharmaceutics: Barriers to Drug Absorption, $2^{\text {nd }}$ ed.; Washington, N., Washington, C., Wilson, C. G., Eds.; CRC Press: Florida, 2001; pp 249-269.

4. Wilson, C. G.; Zhu, Y. P.; Kumala, P.; Rao, L. S.; Dhillon, B. Ophthalmic Drug Delivery. In Drug Delivery and Targeting for Pharmacists and Pharmaceutical Scientists. Hillery, A. M., Lloyd, A. W., Swarbrick, J., Eds.; CRS Press: Florida, 2001; pp 329-353.

5. Wollensak, G.; Spoerl, E.; Seiler, T. Riboflavin / Ultraviolet-A-induced Collagen Crosslinking for the Treatment of Keratoconus. Am J. Ophthalmol. 2003, 135, 620-627.

6. Al-Sabai, N.; Koppen, C.; Tassignon, M. J. UVA / Riboflavin Crosslinking as Treatment for Corneal Melting. Bul. Soc. Belge. Ophthalmol. 2010, 315, 13-17.

7. Hafezi, F.; Kanellopoulos, J.; Wiltfang, R.; Seiler, T. Corneal Collagen Crosslinking with Riboflavin and Ultraviolet A to Treat Induced Keratectasia after Laser in situ Keratomileusis. $J$. Cateract Refr. Surg. 2007, 33, 2035-2040.

8. Sorkhabi, R.; Sedgipoor, M.; Mahdavifard, A. Collagen Cross-Linking for Resistant Corneal Ulcer. Int. Ophthalmol. 2013, 33, 61-66. 
9. Anwar, H. M.; El-Danasoury, A. M.; Hashem, A. N. Corneal Collagen Crosslinking in the Treatment of Infectious Keratitis. Clin. Ophthalmol. 2011, 5, 1277-1280.

10. Kaur, I. P.; Batra, A. Ocular Penetration Enhancers. In Enhancement in Drug Delivery, Touitou, E., Barry, B. W., Eds. CRC Press: Florida, 2007; pp 527-548.

11. Oviedo, C.; Rodriguez, J. EDTA: The Chelating Agent under Environmental Scrutiny. Quim. Nova. 2003, 26, 901-905.

12. Grass, G. M.; Wood, R. W.; Robinson, J. R. Effects of Calcium Chelating Agents on Corneal Permeability. Invest Ophthalmol Vis. Sci. 1985, 26, 110-113.

13. Fang-Sheng, W.; Ching-Ming, C.; Tsong-Teh, K. Effects of $\mathrm{Ca}^{++}$Chelator, $\mathrm{Ca}^{++}$Ionophore and Heatshock Pretreatment on in Vitro Protein Phosphorylation of Rice Suspension Culture Cells. Bot. Bull. Acad. Sinica. 1992, 33, 151-159.

14. Meers, E.; Ruttens, A.; Hopgood, M. J.; Samson, D.; Tack, F. M. G. Comparison of EDTA and EDDS as Potential Soil Amendment for Enhanced Phytoextraction of Heavy Metals. Chemosphere. 2005, 58, 1011-1022.

15. Morrison, P. W. J.; Khutoryanskiy, V. V. Enhancement in Corneal Permeability of Riboflavin using Calcium Sequestering Compounds. Int. J. Pharmaceutics. 2014, 472, 56-64.

16. Pedersen, C. J. Cyclic Polyethers and Their Complexes with Metal Salts. J. Am. Chem. Soc. 1967, 89, 7017-7036.

17. Ouchi, M.; Inoue, Y.; Kanzaki, T.; Hakushi, T. Molecular Design of Crown Ethers. Effects of Methylene Chain Length: 15- to 17-Crown-5 and 18- to 22-Crown-6. J. Org. Chem. 1984, 49, 1408-1412.

18. Steed, J.W. First- and Second-sphere Coordination Chemistry of Alkali Metal Crown Ether Complexes. Coord. Chem. Rev. 2001, 215, 171-221.

19. Boojar, M. M. A.; Goodarzi, F. Cytotoxicity and Levels of Oxidative Stress Parameters in W138 Cells Following 2 Macrocyclic Crown Ethers Treatment. Clin. Chim. Acta. 2006, 364, 321-327.

20. Capel-Cuevas, S.; De Orbe-Payá, I.; Santoyo-González, F.; Capitán-Vallvey, L. F. DoubleArmed Crown Ethers for Calcium Optical Sensors. Talanta. 2009; 78, 1484-1488.

21. Ming-Zhi, S.; Lan-ying, Z.; Xi-ke, G.; Jian-min, D.; De-zhi, S. Microcalorimetric Study on Guest-Host Complexation of Naptho-15-Crown-5 with Four Ions of Alkaline Earth Metals. J. Zhejiang Univ. Sci. 2005, 6, 69-73. 
22. Marjanović, M.; Kralj, M.; Supek, F.; Frkanec, L.; Piantanida, I.; Smuc, T.; Tusek-Bozić, L. Antitumor Potential of Crown Ethers: Structure-activity Relationships, Cell Cycle Disturbances, and Cell Death Studies of a Series of Ionophores. J. Med. Chem. 2007, 50, 1007-1018.

23. Muzzalupo, R.; Nicoletta, F. P.; Trombino, S.; Cassano, R.; Lemma F.; Picci, N. A New Crown Ether as Vesicular Carrier for 5-Fluoruacil: Synthesis, Characterization and Drug Delivery Evaluation. Colloids Surf. B Biointerfaces. 2007, 58,197-202.

24. Darwish, I. A.; Uchegbu, I. F. The Evaluation of Crown Ether Based Niosomes as Cation Containing and Cation Sensitive Drug Delivery Systems. Int. J. Pharm. 1997, 159, 207-213.

25. Roskams, J.; Rodgers, L. Lab Ref: A Handbook of Recipes, Reagents and Other Reference Tools for use at the Bench. CSHL Press: New York, 2002.

26. Anyakora, C.; Afolami, I.; Ehianeta, T.; Onwumere, F. HPLC Analysis of Nicotinamide, Pyridoxine, Riboflavin and Thiamin in Some Selected Food Products in Nigeria. Afr. J. Pharm. Pharmaco. 2008, 2, 029-036.

27. Whiteside, P. J.; Milner, B. A. Atomic Absorption Data Book, $5^{\text {th }}$ ed. Pye Unicam Ltd: Cambridge, 1983.

28. Morrison, P. W. J.; Connon, C. J.; Khutoryanskiy, V. V. Cyclodextrin-Mediated Enhancement of Riboflavin Solubility and Corneal Permeability. Mol. Pharm. 2013, 10, 756762.

29. Terekhova, I. V.; Tikhova, M. N.; Volkova, T. V.; Kumeev, R. S.; Perlovich, G. L. Inclusion Complex Formation of $\alpha$ - and $\beta$-Cyclodextrins with Riboflavin and Alloxazine in Aqueous Solution: Thermodynamic Study. J. Inc. Phenom Macro. 2011, 69, 167-172.

30. Challa, R.; Ahuja, A.; Ali, J.; Khar, R. K. Cyclodextrins in Drug Delivery: An Updated Review. AAPS PharmSciTech. 2005; 6, 329-357.

31. Jarho, P.; Urtti, A.; Pate, D. W.; Suhonen, P.; Jarvinen, T. Increase in Aqueous Solubility, Stability and in vitro Corneal Permeability of Anandamide by Hydroxyl- $\beta$-Cyclodextrin. Int. J. Pharm. 1996, 137, 209-216.

32. Liu, R.; Liu, Z.; Zhang, C.; Zhang, B. Gelucire44/14 as a Novel Absorption Enhancer for Drugs with Different Hydrophilicities: in vitro and in vivo Improvement on Transcorneal Permeation. J. Pharm. Sci.. 2011, 100, 3186-3195.

33. Fujishama, H.; Toda, I.; Yamada, M.; Sato, N.; Tsubota, K. Corneal Temperature in Patients with Dry Eye Evaluated by Infrared Radiation Thermometry. Br. J. Ophthamol. 1996, 80, 29-32. 
34. Abdelkader, H.; Ismail, S.; Hussein, A.; Wu, Z.; Al-Kassas, R.; Alany, R.G. Conjunctival and Corneal Tolerability Assessment of Ocular Naltrexone Niosomes and Their Ingredients on the Hen's Egg Chorioallantoic Membrane and Excised Bovine Cornea models. Int. J. Pharm. 2012, 432, 1-10.

35. OECD, 2013. Bovine Corneal Opacity and Permeability Test Method for Identifying i) Chemicals Inducing Serious Eye Damage and ii) Chemicals Not Requiring Classification for Eye Irritation or Serious Eye Damage. OECD Guidelines for the Testing of Chemicals. OECD Publishing: Paris. doi: http://dx.doi.org/10.1787/9789264203846-en

36. Coffman, R. E.; Kildsig, D. O. Effect of Nicotinamide and Urea on the Solubility of Riboflavin in Various Solvents. J. Pharm. Sci. 1996, 85, 951-954.

37. Zhunuspayev, D. E.; Mun, G. A.; Khutoryanskiy, V. V. Temperature-Responsive Properties and Drug Solubilization Capacity of Amphiphilic Copolymers Based on $N$-vinylpyrrolidone and Vinyl Propyl Ether. Langmuir. 2010, 26, 7590-7597.

38. Higuchi, T., Conners, K. A. Phase-Solubility Techniques. Adv. Anal. Chem. Instrum.. 1965, 4, 117-212.

39. Chang, C. A.; Twu, J.; Bartsch, R. A. pH-Dependant Metal Ion Selectivity by Crown Ether Carboxylic Acid. Inorg. Chem. 1986, 25, 396-398.

40. Inokuchi, Y.; Boyarkin, O. V.; Kusaka, R.; Haino, T.; Ebata, T.; Rizzo, T. R. Ion Selectivity of Crown Ethers Investigated by UV and IR Spectroscopy in a Cold Ion Trap. J. Phys. Chem. A. 2012, 116, 4057-4068.

41. Inoue, Y. Hakushi, T. Enthalpy-Entropy Compensation in Complexation of Cations with Crown Ethers and Related Ligands. J. Chem. Soc. Perkin Trans. 1985, 2, 935-946.

42. Arnaud-Neu, F.; Delgado, R.; Chaves, S. Critical Evaluation of Stability Constants and Thermodynamic Functions of Metal Complexes of Crown Ethers, Pure Appl. Chem. 2003, 75, 71-102.

43. Rawat, N.; Gujar, R.B.; Murali, M.S.; Tomar, B.S.; Manchanda V.K. Thermodynamics of complexation of $\mathrm{Sr}(\mathrm{II})$ and $\mathrm{Ba}(\mathrm{II})$ by 18 -crown-6 in water-ethanol binary mixture using titration calorimetry. Thermochimica Acta 2009, 488, 21-26.

44. Izatt, R.M.; Terry, R.E.; Haymore, B.L.; Hansen, L.D.; Dalley, N.K.; Ayondet, A.G.; christenses, J.J. Calorimetric Titration Study of the Interaction of Several Uni- and Bivalent 
Cations with 15-Crown-5, 18-Crown-6, and Two Isomers of Decyclohexo-18-crown-6 in Aqueous Solution at $25^{\circ} \mathrm{C}$ and $\mu=0.1$. J. Amer. Chem Soc. 1976, 98, 7620-7626.

45. Solov'ev, V. P.; Kazachenko, V.P.; Zavel'skii, V.O.; Govorkova, L.V.; Raevskii, O.A.; The Study of the Complexation of Calcium Chloride and Calcium Nitrate with 18-Crown-6 in Water by the Methods of Solution Calorimetry and NMR ${ }^{43}$ Ca. Koord. Khim. (Rus) 1987, 13, 909-913. 46. Hancock, R. D. A Molecular Mechanics Study of the Selectivity of Crown Ethers for Metal Ions on the Basis of Their Size. J. Incl. Phenom. Mol. Recognit Chem. 1994, 17, 63-80.

47. Malhotra, M.; Majumdar, D. K. Permeation Through Cornea. Indian J. Exp. Biol. 2001, 39, $11-24$.

48. Kaur, I.P.; Garg, A.; Singla, A.K.; Aggarwal, D. Vesicular Systems in Ocular Drug Delivery: an Overview. Int. J. Pharm. 2004, 269, 1-14.

49. Bhattacharya, P.; Epstein, W.; Silver, S. Valinomycin-Induced Uptake of Potassium in Membrane Vesicles from Escherichia Coli. Proc. Natl. Acad. Sci. U. S. A. 1971, 68, 1488-92.

50. Leevy, W.M.; Weber, M.E.; Gokel, M.R.; Hughes-Strange, G.B.; Daranciang, D.D.; Ferdani, R.; Gokel, G.W. Correlation of Bilayer Membrane Cation Transport and Biological Activity in Alkyl-substituted Lariat Ethers. Org. Biomol. Chem. 2005, 3, 1647-52.

51. Al Khateb, K.; Ozhmukhametova, E.K.; Mussin, M.N.; Seilkhanov, S.K.; Rakhypbekov, T.K.; Lau, W.M.; Khutoryanskiy, V.V. In situ gelling systems based on Pluronic F127 / Pluronic F68 formulations for ocular drug delivery. Int. J. Pharm. 2016, 502, 70-79.

52. Rodríguez, I.; Vázquez, J.A.; Pastrana, L.; Khutoryanskiy, V.V. Enhancement and inhibition effects on the corneal permeability of timolol maleate: Polymers, cyclodextrins and chelating agents. Int. J. Pharm. 2017, 529, 168-177. 